\title{
Stanovení vybraných drog a jejich metabolitů v odpadních vodách metodou kapalinové chromatografie
}

\section{DANICA POSPÍCHALOVÁ, DIANA MAREŠOVÁ, VĚRA OČENÁŠKOVÁ, TEREZA ŠAFRÁNKOVÁ, EVA BOHADLOVÁ}

Klíčová slova: odpadní voda - drogy - nikotin - metabolity nikotinu - alkohol - ethylsulfát

\section{SOUHRN}

Epidemiologie odpadních vod byla navržena v roce 2001 ke sledování koncentrace nelegálních drog a jejich metabolitů v odpadních vodách přitékajících do komunálních čistíren odpadních vod, do kterých se zmíněné sloučeniny dostávají z moče konzumentů drog cestou kanalizační sítě. Poprvé byla použita v roce 2005 ke sledování kokainu v Itálii. Postupně byl př́istup aplikován na sledování dalších nezákonných drog jako např. heroin, kanabis nebo stimulantů na bázi amfetaminu. Analýza odpadních vod je velmi slibný způsob k monitorování legálních stimulantů, jako je nikotin a jeho metabolity a alkohol, resp. metabolity alkoholu. Ve VúV TGM, v. v. i., je od roku 2012 rozvíjena metoda LC-MS umožňující současné stanovení řady těchto látek. Příspěvek shrnuje analytické možnosti stanovení a metodiku vyvinutou na pracovišti se zaměřením na analyty nikotin a jeho metabolity a na metabolit alkoholu ethylsulfát, nově doplněné v rámci řešení projektu „Čistá voda - zdravé město: Komunální odpadní voda jako diagnostické médium hlavního města Prahy“ v rámci Konceptu IV.

\section{ÚVOD}

Epidemiologie odpadních vod byla navržena v roce 2001 [1] ke sledování koncentrace nelegálních drog a jejich metabolitů v odpadních vodách přitékajících do komunálních čistíren odpadních vod, do kterých se zmíněné sloučeniny dostávají z moče konzumentů drog cestou kanalizační sítě. Poprvé byla použita v roce 2005 ke sledování kokainu v Itálii [2]. Postupně byl přístup aplikován na sledování dalších nezákonných drog jako např. heroin, kanabis nebo stimulantů na bázi amfetaminu [3-6]. V České republice proběhlo např. sledování v rámci projektu Dragon (projekt Ministerstva vnitra, VG20122015101 Stanovení množství nelegálních drog a jejich metabolitů v komunálních odpadních vodách - nový nástroj pro doplnění údajů o spotřebě drog v České republice) [7]. Sledovány byly metamphetaminy, kokain a jeho metabolity, opioidy, LSD, buprenorfin, metadon a jeho metabolit EDDP, efedrin, tramadol a nor-THC s využitím dřive vyvinuté metodiky [8].

$\checkmark$ rámci řešení projektu "Čistá voda - zdravé město: Komunální odpadní voda jako diagnostické médium hlavního města Prahy" (dále jen Projekt) byly analyzovány možnosti rozšiření stávající metodiky o další zneužívané látky. Na základě literatury a dřivějších prací byly vybrány nikotin a jeho metabolity, metabolit alkoholu ethylsulfát a kathinony (nové syntetické drogy).
Analýza odpadních vod je velmi slibný způsob k monitorování legálních stimulantů, jako je nikotin a jeho metabolity. Avšak koncentrace těchto látek značně kolísá v průběhu roku a často dosahuje velmi nízkých hodnot. Je to způsobeno hlavně nestabilitou nikotinu v odpadní vodě. Proto se sledují hlavně stabilní metabolity - kotinin a trans-3'-hydroxykotinin. V lidském těle je nikotin metabolizován na kotinin (70-80 \%) a nikotin-N'-oxid (4-7\%). Kotinin je potom dále metabolizován na další submetabolity, tj. jenom 10-15\% zkonzumovaného nikotinu je vyloučeno jako kotinin [9]. Část nikotinu přechází do moči nemetabolizována. Nikotin se ale může dostávat do odpadní vody nejen s močí, ale i oplachem z nedopalků cigaret a popela [10, 11]. Dalším zdrojem nikotinu je substituční léčba (nikotinové náplasti a žvýkačky) a elektronické cigarety [11]. Analýza nikotinu v odpadní vodě není specifická a nevystihuje nebezpečnou konzumaci tabáku. Proto se pro kvantifikaci nikotinu v některých studiích využívají např. alkaloidy anabasin a anatabin, které jsou specifické pro sušený tabák, a stanovují se spolu s nikotinem a kotininem jako biomarkery pro konzumaci tabáku v odpadní vodě [12].

Alkoholické nápoje jsou jednou z nejpopulárnějších látek ve společnosti s obsahem psychoaktivní sloučeniny ethanol. Ethanol je v játrech oxidován predevším na acetaldehyd (90-95\%). Malá část (<0,1\%) přechází na metabolity ethylsulfát (EtS) a ethylglukuronid [13]. Ethylglukuronid není vhodný jako biomarker v odpadních vodách, protože je v nich velmi nestabilní [14]. Ethylsulfát je specifický biomarker pro monitorování spotřeby alkoholu. Jedná se o metabolit ethanolu, který indikuje nedávnou konzumaci alkoholu s dobou detekce do 48 hodin u zdravých jedinců a je stabilní v odpadní vodě [14].

Ke stanovení nikotinu a jeho metabolitů se nejvíce používají prístroje LC-MS/ MS [9, 11, 12, 15-20], výjimečně LC-QTOF [21] nebo hybridní MS Q-Exactive s vysokým rozlišením [22-25]. Detekce a kvantifikace se provádí s hmotnostním detektorem typu trojitého kvadrupolu s ionizací v pozitivním módu ESI+. Odpadní vody jako složitá matrice obsahují velké množství koeluujících sloučenin, které mohou ve velké míre ovlivňovat ionizaci sledovaných sloučenin. Proto se před extrakcí přidávají ke vzorku odpadní vody deuterované izomery stanovovaných analytů a kvantifikace se provádí metodou interního standardu [9-12, 15-28]. Ke zvýšení citlivosti stanovení a čištění se používá prekoncentrace vzorku extrakcí na pevné fázi (SPE) v zapojení on-line [25-27] nebo off-line [9, 11, 15-24, 28]. Používají se kolonky Oasis HLB [11, 14, 19-21, 26-28], Oasis MCX [15], StrataX [12]. Pro on-line SPE se používá zejména kolonka Hypersil Gold [23-25]. Stanovení nikotinu a jeho metabolitů se provádí většinou s kolonami s reverzní fází C18 [9-12, 15-28] a středně polární mobilní fází, která obsahuje organickou fázi (nejčastěji acetonitril nebo methanol) a vodnou fázi (voda s prídavkem mravenčanu nebo octanu amonného v proměnlivém poměru podle nastaveného programu gradientu). 
Tabulka 1. Přehled analytů, jejich základní charakteristiky a rozdèlení do metod stanovení

Table 1. Overview of analytes, theirs characteristics and methods of detection

\section{Látka}

\section{6-acetylmorfin}

amfetamin

benzoylecgonin

buprenorfin

diethylamid kyseliny lysergové

diethylamid kyseliny 2-oxo-3-hydroxy-lysergove

efedrin

ethylcathinon

2-ethylidene-1,5-dimethyl-3,3-diphenylpyrrolidin

ethylsulfát

extáze

fentanyl

heroin

kokaethylen

kokain

kotinin

mefedron

metadon

metamfetamin

4-methylethcathinon

metylon

morfin

nikotin

nor-diazepam

nor-fentanyl

nor-mefedron

11-nor-9-karboxy-delta-9-THC

pentedron

tramadol

trans-3-hydroxykotinin

a-pyrrolidinovalerofenon
CAS Number

63690-08-4

2706-50-5

519-09-5

53152-21-9

$50-37-3$

111295-09-1

24221-86-1

51553-17-4

66729-78-0

546-74-7

64057-70-1

437-38-7

561-27-3

529-38-4

50-36-2

486-56-6

1189726-22-4

1095-90-5

$300-42-5$

1266688-86-1

186028-80-8

6009-81-0

54-11-5

1088-11-5

1609-66-1

6941-17-9

56354-06-4

879669-95-1

36282-47-0

34834-67-8

5485-65-4
Zkratka

6ACM

AMP

$\mathrm{BE}$

BUP

LSD

$\mathrm{OH}-\mathrm{LSD}$

EPH

Eth-cat

EDDP

EtS

MDMA

FEN

HER

COE

$\mathrm{CO}$

COT

MMC

MET

MAMP

4-MEC

bk-MDMA

MOR

NIC

Nor-DZP

Nor-FEN

Nor-MMC

nor-THC

PENT

TRAM

T3H-COT

Alfa-PVP

\section{Charakteristika}

metabolit heroinu

stimulancium

metabolit kokainu

opioid, substituční léčba

halucinogen

metabolit LSD

prekurzor pro výrobu pervitinu

syntetický kathinon

metabolit metadonu

metabolit alkoholu

stimulancium

opioidní analgetikum

opioid

metabolit kokainu

stimulancium

metabolit nikotinu

syntetický kathinon

opioid, substituční léčba

pervitin, stimulancium

syntetický kathinon

syntetický kathinon

opioid

alklaloid

metabolit diazepamu, anxiolytikum

metabolit fentanylu

metabolit mefedronu

metabolit THC

syntetický kathinon

opioidní analgetikum

metabolit nikotinu

syntetický kathinon
Metoda

ESI+

ESI+

ESI+

ESI+

ESI+

ESI+

ESI+

ESI+

ESI+

ESI-

ESI+

ESI+

$\mathrm{ESI+}$

ESI+

ESI+

$\mathrm{ESI}+$

ESI+

ESI+

ESI+

ESI+

ESI+

$\mathrm{ESI}+$

ESI+

ESI+

ESI+

ESI+

ESI-

ESI+

ESI+

ESI+

ESI+ 


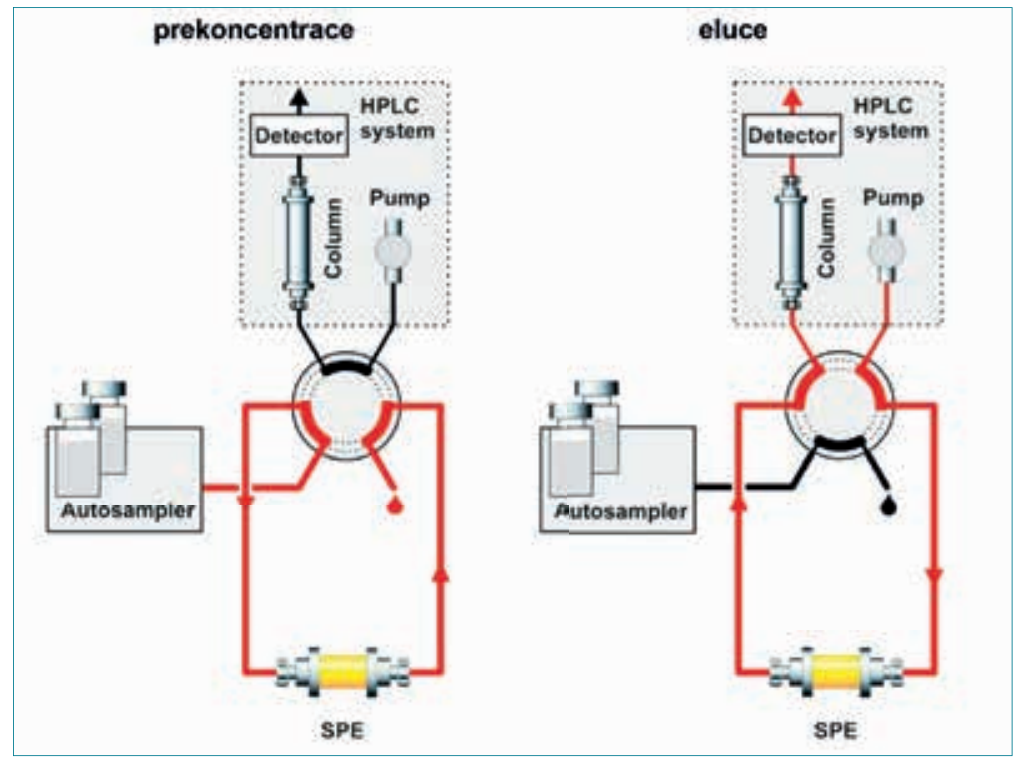

Obr. 1. Zapojení se šesticetným ventilem, eluce proti směru SPE

Fig. 1. Conection of six-way valve, elution against the direction of SPE

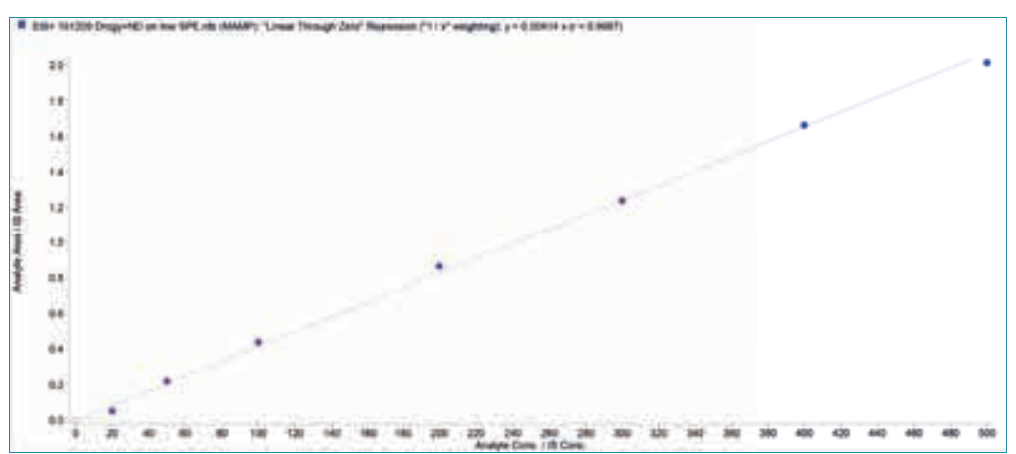

Obr. 2. Ukázka kalibrační křivky pro metamfetamin (MAMP)

Fig. 2. Example of calibration curve (methamphetamine)

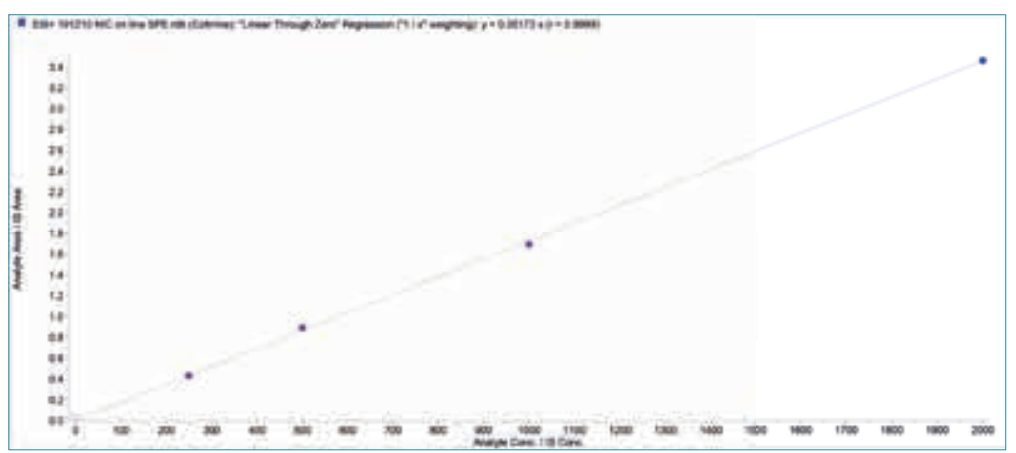

Obr. 3. Ukázka kalibrační krìvky pro kotinin (COT)

Fig. 3. Example of calibration curve (cotinine)

Ke stanovení ethylsulfátu $v$ odpadní vodě se použivá metoda kapalinové chromatografie s hmotnostním detektorem s trojitým kvadrupolem a elektrosprejem jako iontovým zdrojem v negativním módu (ESI-) [13, 29-35]. EtS je polární sloučenina a na tradičních kolonách C18, C8 s reverzní fází je málo zadržován. Proto se rozšírilo jeho stanovení pomocí iontově párové chromatografie. Používají se iontově párová činidla: 5 mM dibutylamonium acetát [24], 7 mM dihexylamonium acetát $[12,25]$. Používané mobilní fáze jsou voda a methanol, iontově párové činidlo se přidává do jedné nebo obou fází. Úspěšně byla ke stanovení EtS použita kolona Synergi Polar-RP (polar endcaped phenylpropyl

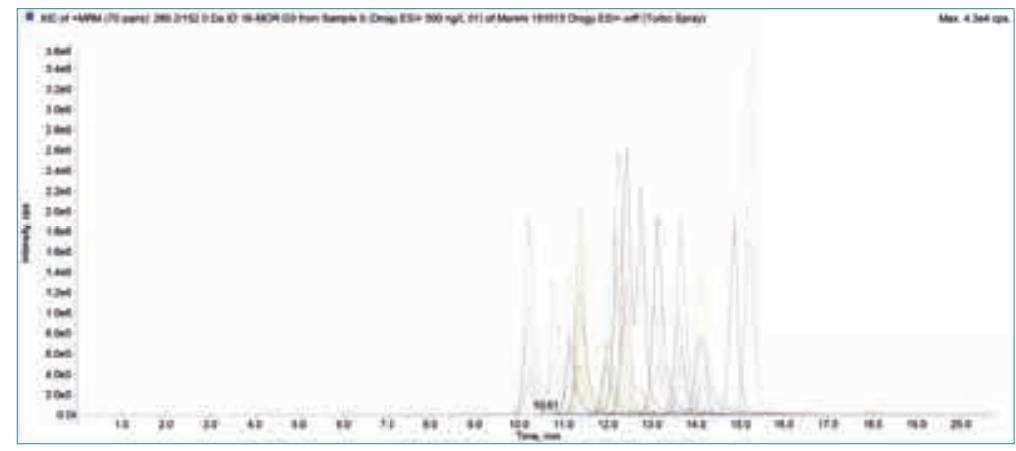

Obr. 4. Ukázka chromatogramu extrahovaných iontů v režimu ESI+ (amfetamin, benzoylecgonin, buprenorphin, EDDP, efedrin, extáze, fentanyl, heroin, kokaethylen, kokain, LSD, metadon, metamfetamin, morfin, nor-diazepam, nor-fentanyl, tramadol) Fig. 4. Example of extracted ion chromatograms in ESI+ (amphetamine, benzoylecgonine, buprenorphine, EDDP, ephedrine, MDMA, fentanyl, heroin, cocaethylene, cocaine, LSD, methadone, methamphetamine, morphine, nor-diazepam, nor-fentanyl, tramadol)

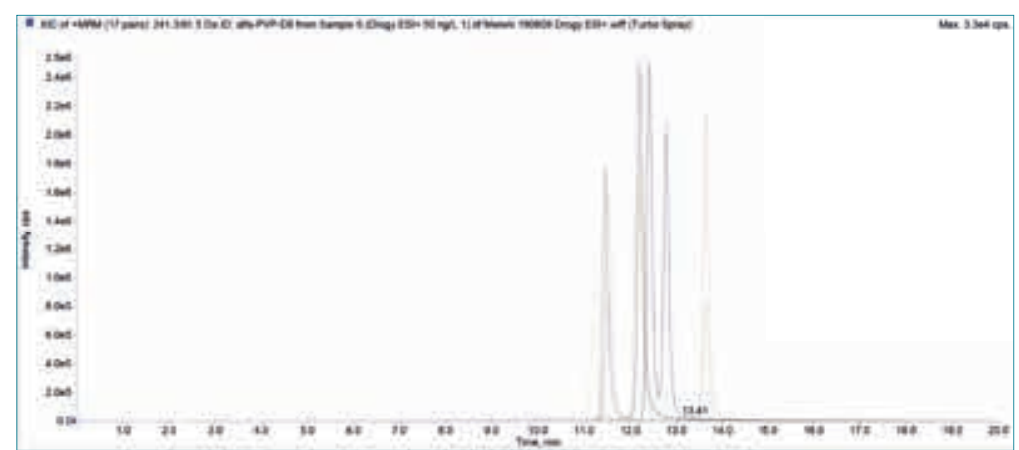

Obr. 5. Ukázka chromatogramu extrahovaných iontů v režimu ESI+ (ethylcathinon, mefedron, 4-methylethcathinon, metylon, nor-mefedron, pentedron, tramadol, trans-3-hydroxykotinin, a-pyrrolidinovalerofenon)

Fig. 5. Example of extracted ion chromatograms in ESI+ (ethylcathinone, mephedrone, 4-methylethcathinone, metylone, nor-mephedrone, pentedrone, tramadol, trans-3-hydroxykotinin, a-pyrrolidinovalerofenone)

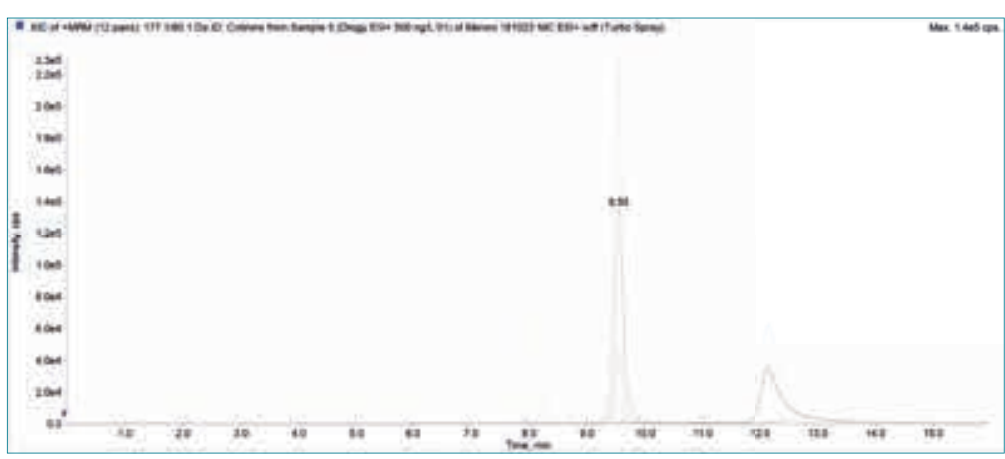

Obr. 6. Ukázka chromatogramu extrahovaných iontů v režimu ESI+ (nikotin, kotinin a trans-3-hydroxykotinin)

Fig. 6. Example of extracted ion chromatograms in ESI+ (nicotine, cotinine and trans-3-hydroxycotinine)

reverzní fáze) [31, 32]. K eluci se používá voda s 0,1 \% kyselinou mravenčí a acetonitril. Ke zlepšení ionizace se za kolonu přidává acetonitril. V poslední době se vyrábějí inertní kolony s navázaným trifunkčním alkylovým ligandem C18, který podporuje retenci polárních sloučenin a eliminuje potřebu př́davku iontových párů [27, 33, 34]. Jsou to např. kolony: Atlantis T3 nebo Chrompack Inertsil ODS-3 (Varian). Používají se s mobilními fázemi voda s 0,1% kyselinou mravenčí a acetonitrilem a s post column prídavkem acetonitrilu ke zvýšení ionizace. 


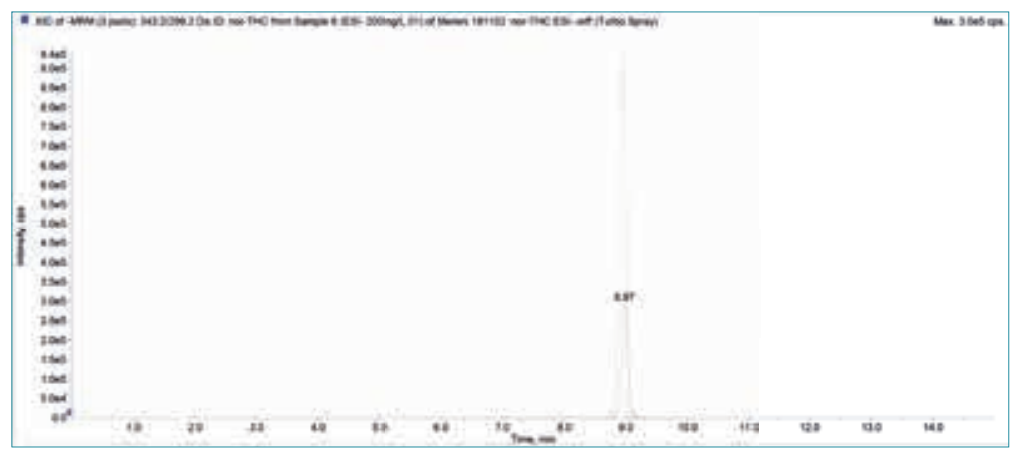

Obr. 7. Ukázka chromatogramu extrahovaných iontů v režimu ESI- (nor-THC)

Fig. 7. Example of extracted ion chromatograms in ESI- (nor-THC)

Stanovení ethylsulfátu se dá provádět i s HILIC kolonami, např. SeQuant ZICHILIC (Merck) a mobilními fázemi 5 mM octan amonný (pH 6,8) a acetonitril [33].

\section{METODIKA}

Postupně bylo v závislosti na chemických vlastnostech a možnostech stanovení jednotlivých látek zavedeno stanovení tři desítek látek metodou kapalinové chromatografie s hmotnostní detekcí za podmínek ionizace elektrosprejem v pozitivním a negativním módu. Přehled stanovovaných analytů včetně jejich základní charakteristiky a rozdělení do postupů stanovení je uveden v tabulce 1 .

Použitá technika: kapalinový chromatograf Agilent 1200 RR s binárním čerpadlem, hmotnostní detektor Applied Biosystem 4000 Q Trap s trojitým kvadrupólem, autosampler Aspec GX-271 (Gilson). Stanovení všech látek bylo prováděno s chromatografickou kololnou Synergi Hydro-RP80A (150 ×2,0 mm, 4 m).

Multireziduální stanovení této skupiny analytů se nedalo provést vzhledem k jejich odlišným chemickým vlastnostem a koncentračním hladinám jejich výskytu. Z tohoto důvodu bylo stanovení rozděleno do čtyř separátních postupů.

Analýzy byly prováděny $v$ odpadní vodě odebírané $v$ nátoku na čistírnu komunálních odpadních vod. Tato voda je velmi komplexní matrice a jako nezbytné se jeví použití vnitřních standardů. Matrice silně ovlivňuje ionizaci. Bylo pozorováno potlačení ionizace vlivem látek př́tomných ve vzorku. Proto bylo pracováno s deuterovanými standardy všech stanovovaných látek.

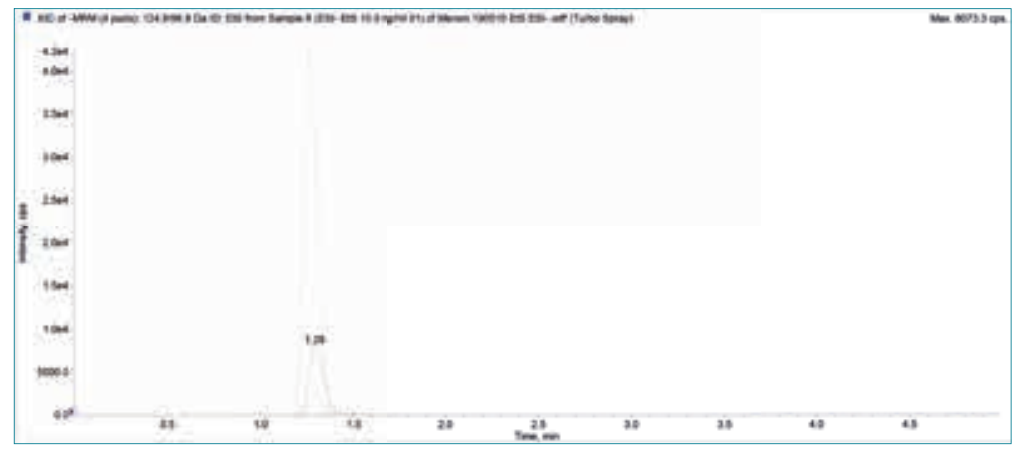

Obr. 8. Ukázka chromatogramu extrahovaných iontů v režimu ESI- (ethylsulfát) Fig. 8. Example of extracted ion chromatograms in ESI- (ethylsulfate)

Pro analýzy se zpracovávají 24hodinové kompozitní vzorky odebírané na nátoku na čistírnu komunálních odpadních vod, které se po odběru uchovávají $\checkmark$ chladu a temnu. Pokud nelze vzorek analyzovat do 72 hodin od odběru, vzorek se zmrazí a do vlastní analýzy se skladuje při teplotě $-20 \pm 4{ }^{\circ} \mathrm{C}$.

Před vlastním stanovením se vzorky odstředí a ze vzorku se odstraní pevné částice filtrací přes jednorázové membránové filtry o porozitě 0,45 $\mu \mathrm{m}$. Po prídavku směsného roztoku vnitřních standardů je vzorek připraven k LC-MS/MS analýze. Před chromatogrfickou analýzou se vzorky zakoncentrují z objemu 1-5 ml on-line SPE (drogy, nikotin a jeho metabolity). K on-line prekoncentraci vzorků byl použit autosampler Aspec GX-271(Gilson) a kolonka Hypersil Gold (20 × 2,1 mm, $12 \mu \mathrm{m})$, na kterou bylo $1-5 \mathrm{ml}$ vzorku vloženo průtokem $0,5 \mathrm{ml} / \mathrm{min}$. Potom byla kolonka ještě promyta $1 \mathrm{ml}$ UHQ vody, aby se dokončil transfer vzorku a odstranily některé interference. Eluce analytů na chromatografickou kolonu byla prováděna mobilní fází jejím prưtokem koncentrační kolonkou v protisměru v zapojení podle obr. 1. Pouze analýza ethylsulfátu se vzhledem k jeho vysokým koncentracím (desítky $\mu \mathrm{g} / \mathrm{l}$ ) provádí bez prekoncentrace s nástřikem $5 \mu \mathrm{l}$ vzorku na kolonu.

Všechny používané chemikálie jsou čistoty p. a. nebo vyšší. Pro kalibraci jsou používány certifikované referenční chemikálie, např. fy Merc, Lipomed, Chromservis. Jako vnitřní standardy jsou použivány deuterované látky, také certifikované. Podmínky kapalinové chromatografie pro jednotlivé postupy shrnuje tabulka 2.

Tabulka 2. Podmínky kapalinové chromatografie

Table 2. Liquide chromatography settings

\section{ESI+}

\section{Drogy}

ESI-

nor-THC

EtS

\begin{tabular}{|c|c|c|c|c|}
\hline \multirow{3}{*}{$\begin{array}{l}\text { SPE on-line } \\
\text { prekoncentrace }\end{array}$} & \multicolumn{3}{|c|}{ Autosampler GX-271 Aspec } & \multirow{3}{*}{-} \\
\hline & \multicolumn{3}{|c|}{ Hypersil Gold $20 \times 2,1 \mathrm{~mm}, 12 \mu \mathrm{m}$} & \\
\hline & $5 \mathrm{ml}$ vzorku & $1 \mathrm{ml}$ vzorku & $5 \mathrm{ml}$ vzorku & \\
\hline Předkolona & \multicolumn{4}{|c|}{ Security guard cartrige AQC18 $4 \times 20 \mathrm{~mm}$} \\
\hline Analytická kolona & \multicolumn{4}{|c|}{ Synergi Hydro - RP80A $150 \times 2,00$ mm, 4 um } \\
\hline Mobilní fáze A & \multicolumn{2}{|c|}{5 mM vodný roztok mravenčanu amonného } & 0,1 \% vodný roztok kyseliny mravenčí & $\begin{array}{l}10 \text { mM vodný roztok octanu } \\
\text { amonného, } \mathrm{pH} 7,6\end{array}$ \\
\hline Mobilní fáze B & \multicolumn{2}{|c|}{5 mM roztok mravenčanu amonného v methanolu } & 0,1 \% roztok kyseliny mravenčí v methanolu & $\mathrm{ACN}: \mathrm{MeOH}(1: 1)$ \\
\hline Průtok mobilní fáze & $300 \mu \mathrm{l} / \mathrm{min}$ & $300 \mu \mathrm{l} / \mathrm{min}$ & $300 \mu \mathrm{l} / \mathrm{min}$ & $400 \mu \mathrm{l} / \mathrm{min}$ \\
\hline Nástřik & - & - & - & $5 \mu l$ \\
\hline
\end{tabular}


Tabulka 3. Meze stanovitelnosti (LOQ) v matrici odpadní voda

Table 3. Limits of quantification for wastewater

\begin{tabular}{|c|c|c|}
\hline Analyt & Zkratka & $\begin{array}{l}\text { LOQ } \\
{[\mathrm{ng} / \mathrm{I}]}\end{array}$ \\
\hline 6-acetylmorfin & $6 \mathrm{ACM}$ & 5,5 \\
\hline amfetamin & AMP & 1,1 \\
\hline benzoylecgonin & $\mathrm{BE}$ & 3,5 \\
\hline buprenorfin & BUP & 2,9 \\
\hline diethylamid kyseliny lysergové & LSD & 0,9 \\
\hline efedrin & $\mathrm{EPH}$ & 2,4 \\
\hline ethylcathinon & Eth-cat & 3,5 \\
\hline 2-ethylidene-1,5-dimethyl-3,3-diphenylpyrrolidin & EDDP & 0,7 \\
\hline ethylsulfát & EtS & $2,3^{*}$ \\
\hline extáze & MDMA & 3 \\
\hline fentanyl & FEN & 2,8 \\
\hline heroin & HER & 2,3 \\
\hline kokaethylen & COE & 0,9 \\
\hline kokain & $\mathrm{CO}$ & 2,5 \\
\hline kotinin & СОT & 50 \\
\hline mefedron & MMC & 2,5 \\
\hline metadon & MET & 0,7 \\
\hline metamfetamin & MAMP & 0,9 \\
\hline 4-methylethcathinon & 4-MEC & 2,7 \\
\hline metylon & bk-MDMA & 2,8 \\
\hline morfin & MOR & 4,8 \\
\hline nikotin & $\mathrm{NIC}$ & 300 \\
\hline nor-diazepam & Nor-DZP & 4,3 \\
\hline nor-fentanyl & Nor-FEN & 2,8 \\
\hline 11-nor-9-karboxy-delta-9-THC & nor-THC & 1,3 \\
\hline tramadol & TRAM & 3,5 \\
\hline trans-3-hydroxykotinin & Т3H-COT & 40 \\
\hline a-pyrrolidinovalerofenon & Alfa-PVP & 5,5 \\
\hline
\end{tabular}

${ }^{*} \mu g / l$

Identifikace a kvantifikace se ve všech prípadech provádí za pomoci vyhodnocovacího systému Analyst ${ }^{\oplus}$ Software. Jednotlivé látky se identifikuji porovnáním retenčních časů s retenčními časy standardů a shodnosti poměru intenzit dvou sledovaných přechodů dané látky ve vzorku a v kalibračním roztoku. Kvantifikace se provádí na základě hodnot vypočtených pomocí kalibračních křivek metodou kalibrace na vnitřní standard (deuterovaný standard). Ve stanovovaném rozsahu byly všechny kalibrační křivky lineární (korelační koeficient 0,99 a lepší).
Pro ukázku jsou na obr. 2-8 uvedeny kalibrační křivky a chromatogramy extrahovaných iontů standardů. Je zobrazen prekurzorový, produktový ion a vnitřní standard.

Meze stanovitelnosti (LOQ) dosažené popsanými postupy v matrici odpadní voda jsou uvedeny v tabulce 3 .

Podrobněji jsou použité analytické metody pro stanovení nikotinu a jeho metabolitů a ethylsulfátu popsány ve sborníku z konference Hydroanalytika 2019 [36].

Pro skupinu syntetických kathinonů byly hledány možnosti snížení mezí stanovitelnosti, protože nebyl zaznamenán pozitivní nález těchto látek (s výjimkou dvou hodnot mefedronu těsně na úrovni LOQ, období hodnocení 2018). Zkoušená metodika vycházela z dřivější metodiky off-line SPE vyvinuté v projektu Program IGA 2013 - Projekt „Nové drogy - analýza trhu epidemiologie užívání a identifikace možnosti pro snižování škod" [37]. Ani při zpracování $500 \mathrm{ml}$ vzorku nebylo dosaženo lepších mezí stanovitelnosti než při on-line SPE metodě [38].

\section{ZÁVĚR}

Pro řešení projektu „Čistá voda - zdravé město: Komunální odpadní voda jako diagnostické médium hlavního města Prahy", ve kterém jsou monitorovány vedle nezákonných drog a jejich metabolitů (včetně syntetických kathinonů) také některá léčiva a další legální drogy, jako jsou ethanol a nikotin, resp. jejich metabolity, byly vypracovány a zvalidovány postupy pro stanovení těchto látek. V závislosti na chemických vlastnostech a možnostech stanovení jednotlivých látek byly o tyto látky rozšiřreny již dříve používané metody kapalinové chromatografie s hmotnostní detekcí za podmínek ionizace elektrosprejem $\checkmark$ pozitivním módu a v negativním módu. Metody byly akreditovány. Celkem jsou uvedenými metodami stanovovány tři desítky látek. Metody rozvinuté ve VúV TGM, v. v. i., splňují požadavky na citlivost pro analýzu většiny zneužívaných drog a jejich metabolitů i dalších látek sledovaných v rámci Projektu.

\section{Literatura}

[1] DAUGHTON CD. Illicit Drugs in Municipal Sewage: Proposed New Nonintrusive Tool to Heighten Public Awareness of Societal Use of Illicit/Abused Drugs and Their Potential for Ecological Consequences, in Pharmaceutical and Personal Care Products in The Environment: Scientific and Regulatory Issues, American Chemical Society: Washington, D.C., 2001, p. 348-364.

[2] ZUCCATO, E. et al Cocaine in surface waters: a new evidence-based tool to monitor community drog abuse. Environ. Health Global Access SCi. Source, 2005, 4, p. 14-20.

[3] VAN NUIJS, A., MOUGEL, J.F., TARCOMNICU, I., et al. Sewage epidemiology: a real-time approach to estimate the consumption of illicit drugs in Brussels, Belgium. Environment International, 2011, 27 p. 612-621.

[4] CASTIGLIONI, S., THOMAS, K.V., KASPRZYK-HORDERN, B., VANDAM, L., and GRIFFITHS, P. Testing wastewater to detect illicit drugs: State of the art, potential and research needs. Science of the Total Environment, 2014, 487, p. 613-620

[5] BEEN, F., BIJLSMA, L., BENAGLIA, L., et al. Assessing geographical differences in illicit drug consumption: A comparison of results from epidemiological and wastewater data in Germany and Switzerland. Drug and Alcohol Dependence, 2016, 161, p. 189-199.

[6] DU, P. Methamphetamine and ketamine use in major Chinese cities, a nationwide reconnaissance through sewage-based epidemiology. Water Research, 2015, Vol. 84, p. 76-84

[7] OČENÁŠKOVÁ, V. Využití epidemiologie odpadních vod pro sledování spotřeby nelegálních dorg a dalších látek $v$ českém a mezinárodním kontextu. VTEl, 2016, roč. 58, č. 6, s. 27-30.

[8] OČENÁŠKOVÁ, V. a kol. Metodika aplikace epidemiologie odpadních vod pro stanovení odnosu nezákonných látek (drog) v České republice. Certifikovalo České ekologické manažerské centrum, 28. pluku 524/25, 10100 Praha 10. Certifikováno 29.12.2015.

[9] LOPES, A., SILVA, N., BRONZE, M.R., FERREIRA, J., and MORAIS, J. Analysis of cocaine and nicotine metabolites in wastewater by liquid chromatography-tandem mass spectrometry. Cross abuse index patterns on a major community. Science of the Total Environment, 2014, 487, p. 673-680.

[10] ORT, CH., ALEXANDER, L.N., VAN NUIJS, A.L.N., BERSET, J.D., LUBERTUS BIJLSM, L., CASTIGLIONI, S., COVACI, A., et al. Spatial differences and temporal changes in illicit drug use in Europe quantified by wastewater analysis. Addiction, 109, p. 1338-1352. 
[11] CASTIGLIONI, S., SENTA, I., BORSOTTI, A., DAVOLI, E., and ZUCCATO, E. A novel approach for monitoring tobacco use in local communities by wastewater analysis. Tob. Control, 2015, 24, p. 38-42. [12] RICO, M., ANDRÉS-COSTA, M.J., and PICÓ, Y. Estimating population size in wastewater-based epidemiology. Valencia metropolitan area as a case study. Journal of Hazardous Materials, $2017,323$.

[13] MASTROIANNI, N., LOPEZ DE ALDA, M., and BARCELO, D. Analysis of ethyl sulfate in raw wastewater for estimation of alcoholconsumption and its correlation with drugs of abuse in the city of Barcelona. Journal of Chromatography, 2014, 1360, p. 93-99.

[14] REID, M.J., LANGFORD, K.H., MøRLAND, J., and THOMAS, K.V. Analysis and Interpretation of Specific Ethanol Metabolites, Ethyl Sulfate, and Ethyl Glucuronide in Sewage Effluent for the Quantitative Measurement of Regional Alcohol Consumption. Alcohol. Clin. Exp. Res., 2011, Vol. 35, No. 9, p. 1593-1599.

[15] KINYUA, J., COVACl, A., MAHO, W., et al. Sewage-based epidemiology in monitoring the use of new psychoactive substances: Validation and application of an analytical method using LC-MS/MS. Drug Test. Analysis, 2015, 7, p. 812-818.

[16] VAN NUIJS, A.L.N., GHEORGE, A., JORENS, P.G., MAUDENS, K., NEELS, H., and COVACI, A. Optimization, validation, and the application of liquid chromatography-tandem mass spektrometry for the analysis of new drugs of abuse in wastewater. Drug Test. Analysis, 2014, 6, p. 861-867.

[17] CASTIGLIONI, S. Assessing illicit drugs in wastewater: Advances in wastewater-based drug epidemiology publication of the European Monitoring Centre for Drugs and Drug Addiction. EMCDDA, 2016 .

[18] JONES, J. SPE-LC-MS/MS Method for the Determination of Nicotine, Cotinine, and Trans-3hydroxycotinine in Urine, appl. Note 20709. Thermo Fisher Scientific, Runcorn, Cheshire, UK.

[19] HUERTA-FONTELA, M., GARCELAN, M.T., and VENTURA, F. Ultraperformance liquid chromatography-tandem mass spektrometry analysis of stimulatory drugs of abuse in wastewater and surface waters. Anal. Chem., 2007, 79, p. 3821-9.

[20] BUENO, M.J., UDES, S., and HERNANDO, M.D. Evaluation of selected ubiquitous contaminants in the aquatic environment and their transformation products. A pilot study of their removal from a sewage treatment plant. Wat. Res., 2011, 45, p. 2331-41.

[21] BAZ-LOMBA, J.A., SALVATORE, S., GRACIA-LOR, E., et al. Comparison of pharmaceutical, illicit drug, alcohol, nicotine and caffeine levels in wastewater with sale, seizure and consumption data for 8 European cities. BMC Public Health, 2016, 16, p. 1035.

[22] HERNANDEZ, F., CASTIGLIONI, S., COVACI, A., et al. Mass spectrometric strategies for the investigation of biomarkers of illicit drug use in wastewater. Mass Spectrometry Reviews, 2016 by Wiley Periodicals. DOI 10.1002/mas.

[23] FEDOROVA, G., RANDAK, T., LINDBERG, R.H., and GRABIC, R. Comparison of the quantitative performance of a Q-Exactive high-resolution mass spectrometer with that of a triple quadrupole tandem mass spectrometer for the analysis of illicit drugs in wastewater. Rapid Commun. Mass Spectrom., 2013, 27, p. 1751-1762.

[24] MACKULAK, T., GRABIC, R., GÁL, M., and BIROŠOVÁ, L. Evaluation of different smoking habits during misic festivals through wastewater analysis. Environ. Toxicol. and Pharmacology, 2015, 40, p. 1015-1020.

[25] MACKULAK, T., BIROŠOVÁ, L., GRABIC, R., and ŠKUBÁK, J. National monitoring of nicotine use in Czech and Slovak Republic based on wastewater analysis. Environ. Sci. Pollut. Res., 2015, DOI: 10.1007/ s11356-015-4647-7.

[26] SENTA, I., GRACIA-LOR, E., BORSOTTI, A., and ZUCCATO, E. Wastewater analysis to monitor use of caffeine and nicotine and evaluation of their metabolites as biomarkers for population size of caffeine and nicotine and evaluation of
assessment. Water research, 2015, 7, 4, p. 23-33.

[27] TSCHARKE, B.J., WHITE, J.M., and GERBER, J.P. Estimate of tabacco use by wastewater analysis of anabasine and anatabine. Drug Test Anal, 2016, Jul 8(7), p. 702-707.

[28] WANG, D.G., DONG, Q.Q., DU, J., et al. Using Monte Carlo simulation to asses variability and uncertainty of tobacco consumption in a city by sewage epidemiology. BMJ Open 2016, 6:e010583. doi:10.1136/bmjopen-2015-010583

[29] RYU, Y., BARCELO, D., BARRONE, L.P., et al. Comparative measurement and quantitative risk assessment of alcohol consumption through wastewater-based epidemiology: An international study in 20 cities. Science of the Total Environment, 565, 2016, p. 977-983.

[30] BOOGAERTS, T., COVACI, A., KINYUA, J., NEELS, H., and VAN NUIJS, L.N. Spatial and temporal trends in alcohol consumption in Belgian cities: A wastewater-based approach. Drug and Alcohol Dependence, 2016, 160, p. 170-176.

[31] DRESEN, S., WEINMANN, W., and WURST, F.M. Forensic Confirmatory Analysis of Ethyl Sulfate A New Marker for Alcohol Consumption - by Liquid-Chromatography/Electrospray lonization Tandem Mass Spectrometry. American Society for Mass Spectrometry, 2004. Published by Elsevier Inc 1044-0305/04, DOI: 10.1016/j.jasms.2004.08.004.

[32] ALBERMANN, M.E., MUSSHOFF, F., and MADEA, B. A High-Performance Liquid ChromatographicTandem Mass Spectrometric Method for the Determination of Ethyl Glucuronide and Ethyl Sulfate in Urine Validated According to Forensic Guidelines. J. Chromatogr. Sci., 2012, Jan, 50(1), p. 51-56.

[33] AL-ASMARI, A.I., ANDERSON, R.A., and APPELBLAD, P. Direct Determination of Ethyl Glucuronide and Ethyl Sulfate in Postmortem Urine Specimens Using Hydrophilic Interaction Liquid Chromatography-Electrospray lonization-tandem Mass Spectrometry. J. Anal. Tox., 2010, 34, p. 261-272. [34] POLITI, L., MORINI, L., GROPPI, A., et al. Direct Determinatin of the ethanol metabolites ethyl glucuronide and ethyl sulfate in urine by liquid chromatography/electrospray tandem mass spektrometry. Rapid Commun. Mass Spectrom., 2005, 19, p. 1321-1331.
[35] LI, S., LAYNE, J., COUNTRYMAN, S., et al. A Sensitive, Specific, Accurate, and Fast LC-MS-MS Method for Measurement of 42 Ethyl Glucuronide and Ethyl Sulfate in Human Urine. LCGC North America, Jul 01, 2011, Vol. 29, Issue 7.

[36] POSPÍCHALOVÁ, D., MAREŠOVÁ, D., ŠAFRÁNKOVÁ, T. a OČENÁŠKOVÁ, V. Metody stanovení nikotinu a jeho metabolitů a ethylsulfátu v odpadní vodě. In: SÝKORA, V. a KULAJOVÁ, H. Sborník 8. konference Hydroanalytika 2019. Praha, 2019, s. 61-67. ISBN 978-80-904986-4-8.

[37] KVÍČALOVÁ, M. a POSPÍCHALOVÁ, D. Nové psychoaktivni látky v České republice: výskyt, rizika a souvisejicí opatření. Klinika adiktologie 1. LF UK v Praze a VFN v Praze, 2015.

[38] BOHADLOVÁ, E., OČENÁŠKKOVÁ, V., ŠAFRÁNKOVÁ, T. a JANDA, V. Optimalizace metody stanovení vybraných syntetických drog $\vee$ komunálních odpadních vodách. In: SÝKORA, V. a KULAJOVÁ, H. Sborník 8. konference Hydroanalytika 2019. Praha, 2019, s. 45-47. ISBN 978-80-904986-4-8.

\section{Autoři}

Ing. Danica Pospíchalová

凶danica.pospichalova@vuv.cz

RNDr. Diana Marešová, Ph.D.

凶diana.maresova@vuv.cz

Ing. Věra Očenášková

凶vera.ocenaskova@vuv.cz

\section{Bc. Tereza Šafránková}

凶tereza.safrankova@vuv.cz

Ing. Eva Bohadlová

凶eva.bohadlova@vuv.cz

Výzkumný ústav vodohospodářský T. G. Masaryka, v. v. i.

Příspěvek prošel lektorským řizením.

\section{DETERMINATION OF SELECTED ILLICIT DRUGS IN WASTEWATER USING LIQUID CHROMA- TOGRAPHY TANDEM MASS SPECTROMETRY}

\section{POSPICHALOVA, D.; MARESOVA, D.; OCENASKOVA, V.; SAFRANKOVA, T.; BOHADLOVA, E.}

TGM Water Research Institute, p.r.i.

Keywords: wastewater - illicit drugs - nicotine nicotine metabolites - alcohol - ethylsulfate

The wastewater-based epidemiology approach to the analysis of illicit drugs was conceptualized in 2001 and for the first time was applied in 2005 for cocaine estimation in Italy. Further, other illicit drugs as heroine, cannabis and amphetamine have been estimated. Illicit drugs have been measured in TGM Water Research Institute, p.r.i., since 2012. This paper describes analytical possibilities of determination of illicit drugs in wastewater and method evaluated in TGM Water Research Institute, p.r.i., focusing on nicotine and its metabolites and ethylsulfate, the analytes, what were implemented during the project within the Concept IV. 